\title{
急性期破裂脳動脈瘤の治療
}

一血管内治療を第一選択にして一

園部眞, 中居 康展

\section{Treatment for Ruptured Cerebral Aneurysm in Acute Stage: GDC Embolization as the First Choice Treatment}

Makoto Sonobe, M.D. and Yasunobu NAKAI, M.D.

Department of Neurosurgery, Mito National Hospital, Mito, Japan

Summary: We have treated 187 ruptured aneurysms with Guglielmi Detachable Coils (GDC) in acute Stage among 407 patients of subarachnoid hemorrhage admitted to our hospital. Of these cases, the condition of 147 patients was too poor to allow treatment. Seventy-three were treated by neck clipping. One hundred forty-six (78\%) of SAH patients treated by GDCs were independent on discharge. Symptomatic vasospasm was reported in $14.7 \%$ of patients. The permanent morbidity rate is $3.5 \%$ and 2 patients died (1.4\%). Although the long-term results remain to be determined, embolization with GDC is a safe and promising treatment for cerebral aneurysms.

\author{
Key words: \\ - cerebral aneurysm \\ - subarachnoid hemor- \\ rhage \\ - Guglielmi Detachable \\ coil \\ - embolization
}

Surg Cereb Stroke

(Jpn) 32: 271-274, 2004

\section{はじめに}

現在の脳動脈瘤に対する治療のゴールドスタンダードは 開頭クリッピング術である．特にテント上で，術前グレー ドの良い動脈瘤の術後成績および長期予後は良好で，本邦 では開頭クリッピング術を第一選択としている施設が多 い.そして, 開頭クリッピング術でアプローチ困難な部位 の動脈瘤 (内頸動脈の眼動脈部・海綿静脈洞部や後頭蓋窩 の動脈瘤など), 〈も膜下出血重症例, 全身合併症を有す る患者, 高齢者などがGuglielmi Detachable coil (GDC)に よる血管内治療の対象と考えられている。一方，動脈瘤の 血管内治療は, 手術侵襲がより少なく, 術後管理が容易で,
脳血管攣縮の評価もしやすいなどの利点があり，この治療 法を第一選択にする施設も増えてきている．2002年に発 表された, いわゆるISATは, 両治療法の比較に関して衝 撃的な結果であった ${ }^{9)}$.

GDCは，1991年 Guglielmi らにより脳動脈瘤の塞栓用 に開発されたプラチナ製のマイクロコイルである ${ }^{5)}$.その 特徵は, 素材的に非常に柔らかく, 離断する前には動脈瘤 の大きさや形状に合わせて出し入れが可能であることと, デリバリーワイヤーとの接合部を電気分解で切断する機構 のため，一切外力をかけずに離脱できる点である．このコ イルが開発されたことにより，脳動脈瘤の塞栓術は，より 安全で確実性の高い手技となった。本邦でも1997年 3 月 独立行政法人国立病院機構 水戸医療センター 脳神経外科(受稿日 2003. 8. 29)〔連絡先： $7310-0035$ 茨城県水戸市東原 3-2-1 独立行 政法人国立病院機構 水戸医療センター 園部 眞] [Mailing address: Makoto SonobE, M.D., Department of Neurosurgery, Mito Medical Center, National Hospital Organization, 3-2-1 Higashihara, Mito, Ibaraki 310-0035, Japan] 
Table 1 Repartition of patients of subarachnoid hemorrhage

\begin{tabular}{lcc}
\hline & Cases & $\%$ \\
\hline No treatment & 147 & 36.1 \\
Embolization & 187 & 45.9 \\
Clipping & 73 & 18.0 \\
\hline Total & 407 & \\
\hline
\end{tabular}

に保険適応が認められ，脳動脈瘤の血管内治療症例は急速 に増加しつつある．われわれは，種々の器具を用いた脳動 脈瘤の血管内治療経験と, 諸家の GDCによる治療成績の 報告 ${ }^{4)}$ 5) よりそのポテンシャルを確信し, 現在 GDCによ る塞栓術を動脈瘤治療の第一選択としてきている。本稿で は，破裂脳動脈瘤急性期の塞栓術について，若干の考察を 加え報告する。

\section{適応}

GDC 塞栓術の適応を考える際, 最も重要なのは, 動脈 瘤の形態で, 安全確実にマイクロカテーテルを瘤内に挿入 留置でき，GDCを密に充 できる形をしているかどうか である。具体的には，他施設の適応 ${ }^{2) 8}$ を参考にして，以 下の条件を満たす場合を GDC 塞栓術の適応としている.

(1)動脈瘤が血管造影で明らかな neckを有する.

(2)動脈瘤の dome の最大径が $2 \mathrm{~mm}$ 以上で $15 \mathrm{~mm}$ 以下で ある。

(3)動脈瘤の neck が広くなく, 瘤の形が平血状でない.

(4)器質化した瘤内血栓がない.

(5)大きな頭蓋内血腫を伴わない.

(6)動脈硬化や血管の蛇行が極端に強くない.

\section{対 象}

対象は，1997年 3 月から 2003 年 10 月まで国立水戸病院 に入院したくも膜下出血の患者 407 人である.われわれの 施設には第 3 次救命救急センターが併設されているため, くも膜下出血の急性期患者が担送されてくることが多い. その中の $36.1 \%$ (147 例) が治療できずに死亡し， $45.9 \%$ (187 例) で GDC 塞栓術が行われ，18.0\% (73 例)で開頭クリッピ ングが行われた (Table 1). GDC 塞栓術と開頭クリッピン グの比率は $72 ： 28$ である.

\section{方法}

最初に患者の状態および動脈瘤の形態についての検討が 必要である，塞栓術は低侵襲といわれているが，出血傾向 の有無などを含め, 血液, 生化学的検査は必須で, 特に本 手技では多量の造影剂を要することが多く，腎機能を術 前・術後にわたって評価しておく必要がある。また，塞栓
Table 2 Locations of the aneurysms

\begin{tabular}{lc}
\hline Anterior communicating artery & 67 \\
Internal carotid artery & 59 \\
(ICPC & $38)$ \\
Middle cerebral artery & 23 \\
Basilar tip & 13 \\
Distal anterior cerebral artery & 12 \\
Vertebral artery & 9 \\
Posterior cerebral artery & 2 \\
Al portion & 2 \\
\hline & Total \\
\hline
\end{tabular}

(ICPC: Internal cerebral artery-posterior communicating artery)

術を行う場合は, 開頭・クリッピング術に比べて, より詳 細な血管撮影の検討が必要である。特に塞栓術中の digital angiography (DSA) および透視の角度, すなわち best working angle の設定は非常に重要で, 塞栓術の成否を分 けるといっても過言ではない. 動脈瘤近傍のすべての血管 と neck との位置関係が明らかとなる角度を設定すること で，GDCの密な充 が可能となり，GDCの逸脱もすぐに 発見可能となる。最近実用化された 3 D-angiographyは， 1 回の撮影による情報で best working angleを捜すことが でき，術者および患者の負担を軽減させるのに有用である (Fig. 1). もちろん患者の家族との話し合いを十分に行い, 病態の説明, 開頭・クリッピング術と塞栓術のメリット, デメリットを説明し，確固たるインフォームドコンセント のもと, 不必要なトラブルを回避するようにしなければな らない。塞栓術は，全例全身麻酔下で施行している。全身 状態を安定化できるし, 患者を無動化し, より鮮明な血管 造影やロードマップ機能を使用できるようになる，両側の 大腿動脈を穿刺できるように準備して，通常は右側から 6 または7フレンチのシースを大腿動脈に留置する.ついで 内頸動脈にガイディングカテーテルを petrosal segment のカーブの手前に留置する. マイクロカテーテルの操作に は熟練を要する. GDCに対応した2マーカーのマイクロ カテーテルと,それに適合したガイドワイヤーを選択して, マイクロカテーテル先端を動脈瘤内に誘導する。動脈瘤の 大きさを 3 方向から測定し, 適合するコイルを選択する. 最初のコイルで瘤内にコイルの外枠を形成し, 順次内部を 埋めていくことにより密な充 をはかる.

抗凝固療法に関しては, 瘤内に最初のコイルを入れたの ちに全身へパリン化することを原則にしている．塞栓術後 はへパリンをリバースせずに，数時間ぐらい経過してから シースを抜去，止血している。しかし，コイルが血管腔に 広く露出しているときは, 10000 単位/日で $1 \sim 3$ 日間抗凝 固療法を続けたのち，シースを抜去している。抗血小板療 法は，腰椎ドレナージをしていたり，急な血管撮影が必要 

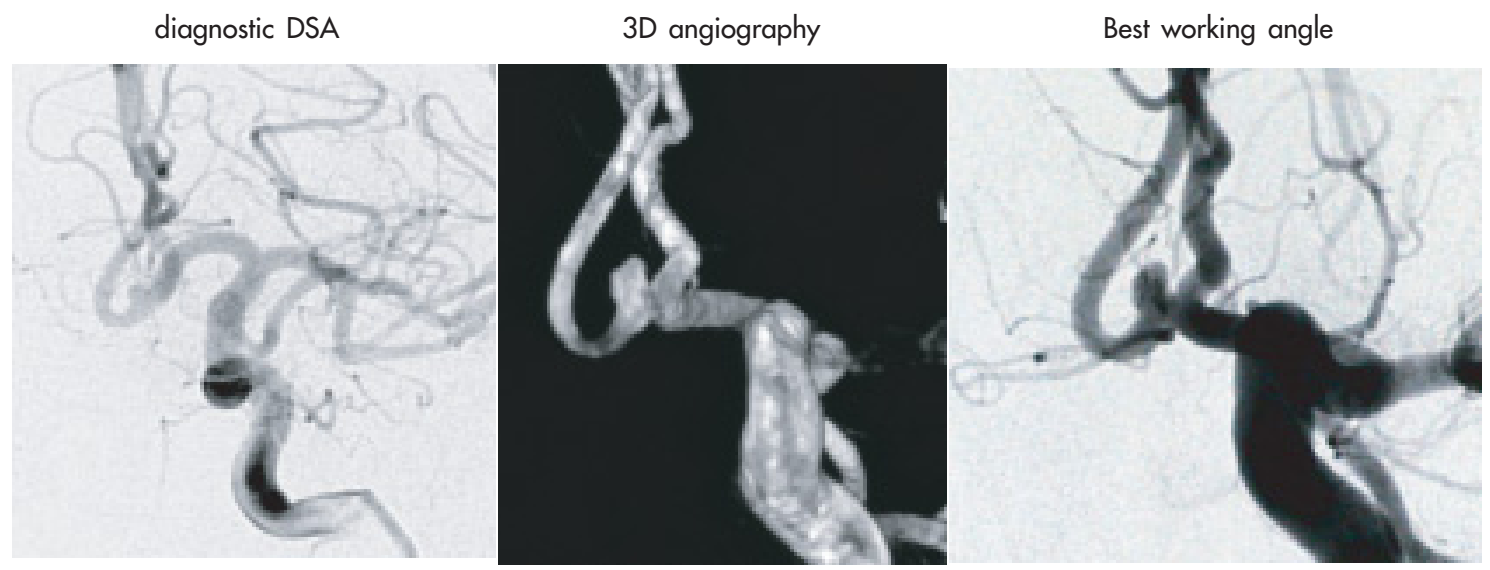

Fig. 1

Table 3

\begin{tabular}{crrrrrrr}
\hline & \multicolumn{7}{c}{ Glasgow Outcome Scale } \\
\hline & \multicolumn{1}{c}{1} & 2 & 3 & 4 & 5 & total \\
\cline { 2 - 8 } & I & 18 & & 1 & & & 19 \\
Hunt \& Kosnik & II & 54 & 5 & 4 & 2 & 1 & 66 \\
Grade & II & 41 & 3 & 3 & & 4 & 51 \\
at Embolization & IV & 16 & 7 & 10 & 3 & 7 & 43 \\
& $V$ & 1 & 1 & & 1 & 5 & 8 \\
\cline { 2 - 8 } & total & 130 & 16 & 18 & 6 & 17 & 187 \\
& \multicolumn{7}{c}{$(78 \%)$} \\
\hline
\end{tabular}

だったりするために，行っていない。

破裂動脈瘤急性期の塞栓術では, くも膜下血腫の直接的 な除去ができないため, 脳血管攣縮の頻度が高まることが 懸念された。その対策としてわれわれは, 腰椎ドレナージ を挿入することで, 積極的にくも膜下血腫の除去を行って いる. また, 入院時の CT で脳底槽のハンスフィールドナ ンバーが70を超えているときには, tPA (tissue plasminogen activator)の髄注を行っている.この他の脳血管攣縮 に対する治療としては，トリプル $\mathrm{H}$ 療法を開頭術の場合 と同様に行っている7 ${ }^{12)}$. 治療の転帰は, 退院後 3 力月で 評価した。

\section{結 果}

1）GDC 塞栓術を行った動脈瘤の部位別症例数をみたの が (Table 2)である. 破裂動脈瘤では中大脳動脈瘤が全体 の $12 \%$ と少なかった。開頭クリッピングになる症例が多い ためである，後頭蓋窩の動脈瘤は $12.8 \%$ であり，当科では 1997 年 3 月から後頭蓋窩の動脈瘤の手術は一件しか行わ れていない。

2）治療時の Hunt \& Kosnik gradeとGOSを示したの
Table 4 Cases over 75-year-old

\begin{tabular}{|c|c|c|c|c|c|c|c|}
\hline & \multicolumn{7}{|c|}{ Glasgow Outcome Scale } \\
\hline \multirow{7}{*}{$\begin{array}{c}\text { Hunt \& Kosnik } \\
\text { Grade } \\
\text { at Embolization }\end{array}$} & & 1 & 2 & 3 & 4 & 5 & total \\
\hline & I & & & & & & \\
\hline & $\|$ & 6 & 1 & & 1 & & 8 \\
\hline & III & 8 & 1 & & & 3 & 12 \\
\hline & IV & 2 & 3 & 1 & & 2 & 8 \\
\hline & V & & & & & & \\
\hline & \multicolumn{7}{|c|}{$(75 \%)$} \\
\hline
\end{tabular}

が (Table 3)である. GDC 塞栓術を行った 187 例中，予後 良好群 (GOS 1，2) が78\% であった。一方，開頭クリッピ ングを行った 73 例でも予後良好群 $75 \%$ と同等の成績であ った。75歳以上の破裂脳動脈瘤では，塞栓術を行ったの が 28 例で，21例 (75\%) が予後良好であった（Table 4).

3）脳血管攣縮については，塞栓術を行った 187 例中, 術前から神経脱落症状があり，評価が困難な症例を除き， 142 例 (75.9\%) で検討可能であった (Table 5). 腰椎ドレナ ージは 136 例で施行され，36例で tPAが髄注されている. 症候性脳血管攣縮を発現したのが 21 例 (14.7\%), 症状が残 存したのが 5 例 (3.5\%), 死亡 2 例 (1.4\%)であった.

\section{考 察}

われわれは，1997年 3 月から，コイル塞栓術を動脈瘤 の治療の第一選択として行ってきた. 塞栓術の適応を決め, 実践してみると, 破裂中大脳動脈瘤が適応になりにくく, 一方，後頭蓋窩の動脈瘤はほとんどが塞栓術で治療されて いた。諸外国の報告も同様の結果になっている ${ }^{13)}$ 。破裂 動脈瘤の治療成績は, 予後良好の症例が $78 \%$ であった。 開頭・クリッピングを中心にした，当施設における，本シ 
Table 5 Vasospasm after SAH

\begin{tabular}{|c|c|c|c|c|c|}
\hline Total cases 187 & & & & & \\
\hline Evaluation cases & 142 & $(75.9 \%)$ & & & \\
\hline Spinal drainage $(+)$ & 136 & & Symptomatic & morbidity & mortality \\
\hline & & & Vasospasm & moribialiy & \\
\hline & tPA $(+)$ & 36 & 7 & & 2 \\
\hline & tPA $(-)$ & 100 & 13 & 4 & \\
\hline Spinal drainage $(-)$ & 6 & & 1 & 1 & \\
\hline & & & $\begin{array}{l}21 \\
1147 \%\end{array}$ & $\begin{array}{l}5 \\
135 \%\end{array}$ & 2 \\
\hline
\end{tabular}

リーズ以前の治療成績は 314 例中，予後良好の症例が 197 例 (63\%)であった。単純に両者を比較することは困難であ るが, 治療成績が下がっていることはないと判断している. また最近発表された開頭・クリッピングの成績(予後良好 が全体の $75 \%)^{6)}$ に比較しても，今回の成績は悪くはない. 高齢者における塞栓術の治療成績も, 若年者と同様であっ た．高齢者だから塞栓術を選択するというのではなく，発 症前の状態や術前状態から判断して治療している結果だと 考えている.

塞栓術後の症候性脳血管攣縮は $14.7 \%$ で，同時期に開頭 術を行って，症候性脳血管攣縮の評価ができた 71 例中で の $25.0 \%$ に比較して少なかったが，統計学的には有意でな かった. mortality と morbidity 合わせて $4.9 \%$ であったが, 開頭・クリッピングを行っている施設 $(3.4 \%)^{1) 3)}$ とほぼ同 等であり，〈も膜下血腫の直接的な除去ができないため, 脳血管攣縮の頻度が高まることはないと考えている。

\section{結＼cjkstart論}

1. 1997 年 3 月から，コイル塞栓術を動脈瘤の治療の第一 選択として行ってきた。

2. 治療成績は開頭手術を中心に治療した場合に比べて劣 らないし，脳血管攣縮に対しても十分対応できる.

3.脳動脈瘤の GDCによる塞栓術は低侵襲である。しかし 本治療法は, 従来の開頭手術に取って代わるものでは なく, 個人の技量, 施設の内容によって取捨選択され, 脳動脈瘤の治療成績の向上に寄与するものでなくては ならない。

\section{文献}

1) Bell TE, Kongable GL: Innovations in aneurysmal subarachnoid hemorrhage: intracisternal t-PA for the prevention of vasospasm. J Neurosci Nurs 28: 107-113, 1996

2) Byrne JD, Molyneux AJ, Brennan RP, et al: Embolization of recently ruptured intracranial aneurysms. $J$ Neurol Neurosurg Psychiatry 59: 616-620, 1995
3) Findlay JM, Kassel NF, Weir BK, et al: A randomized trial of intraoperative, intracisternal tissue plasminogen activator for the prevention of vasospasm. Neurosurgery 37: 168-178, 1995

4) Graves VB, Strother CM, Duff TA, et al: Early treatment of ruptured aneurysms with Guglielmi detachable coils: effect on subsequent bleeding. Neurosurgery 37: 640-648, 1995

5) Guglielmi G, Vinuela F, Dion J, et al: Electrothrombosis of saccular aneurysms via endovascular approach. Part 1: Electrochemical basis, technique, and experimental results. J Neurosurg 75: 1-7, 1991

6）石川達哉, 上山博康, 勝又 研, ほか：開頭直達手術によ る破裂䐉動脈瘤の治療成績. The Mt Fuji Workshop on CVD 20: 25-28, 2002

7) Kinugasa K, Kamata I, Hirotsune N, et al: Early treatment of subarachnoid hemorrhage after preventing rerupture of an aneurysm. $J$ Neurosurg 83: 34-41, 1995

8）松丸祐司，園部 眞，増田良一，ほか：破裂脳動脈瘡に対 する Guglielmi detachable coilによる塞栓術. 脳卒中の外科 28: 207-212, 2000

9) Molyneux A, Kerr R, Stratton I, et al: International Subarachnoid Aneurysm Trial (ISAT) Collaborative Group: International Subarachnoid Aneurysm Trial (ISAT) of neurosurgical clipping versus endovascular coiling in 2143 patients with ruptured intracranial aneurysms: a randomised trial. Lancet 360 (9342): 1267-1274, 2002

10) Moret J, Pierot L, Boulin A, et al: Endovascular treatment of anterior comunicating artery aneurysms using Guglielmi detachable coils. Neuroradiology 38: 800, 1996

11) Moret J, Cognard C, Weill A, et al: The "Remodelling technique in the treatment of wide neck intracranial aneurysms. Interventional Neuroradiology 3: 21-35, 1997

12) Murayama Y, Malisch T, Guglielmi G, et al: Incidence of cerebral vasospasm after endovascular treatment of acutely ruptured aneurysms: report on 69 cases. $J$ Neurosurg 87: 830-835, 1997

13) Nichols DA, Brown R, Thielen KR, et al: Endovascular treatment of ruptured posterior circulation aneurysms using electrolytically detachable coils. J Neurosurg 87: 374, 1997

14) Vinuela F, Duckwiler G, Mawad M: Guglielmi detachable coil embolization of acute intracranial aneurysm I. perioperative anatomical and clinical outcome in 403 patients. J Neurosurg 86: 475-482, 1997 